Peran Kepuasan Kerja sebagai Mediasi Variabel terhadap Kinerja

\title{
The Role Of Job Satisfaction Mediation Variables On The Performance
}

\author{
Veramika BR Sembiring1, Pandapotan Na Uli Sun Siregar1, Mochammad Fahlevi2* \\ 1) Faculty of Economics, Darma Agung University, Indonesia \\ 2)Management Department, BINUS Online Learning, Bina Nusantara University, Indonesia 11480
}

*Coresponding Email: mochammad.fahlevi@binus.ac.id

\begin{abstract}
Abstrak
Industri perhotelan menghadapi serangkaian tantangan yang berat saat ini. Beberapa di antaranya relatif baru, seperti meningkatnya perdagangan digital, meningkatnya pengaruh media seluler dan sosial, dan penurunan loyalitas merek secara umum. Dalam tantangan globalisasi saat ini seperti peluang pasar yang berkembang, menekan pemegang saham untuk hasil jangka pendek, terus kurangnya kepercayaan tamu, dan kurangnya karyawan berbakat. Penelitian ini dilakukan dengan jumlah sampel 347 karyawan hotel budget dari beberapa grup budget hotel yang berada di wilayah Jakarta. Metode penelitian kuantitatif menggunakan SEM dengan alat bantu SmartPLS 3.0 yang digunakan dalam penelitian ini bertujuan untuk memprediksi analisis jalur antar konstruk. Kepuasan kerja juga merupakan faktor penting dalam budget hotel karena beberapa faktor yang mempengaruhi kinerja karyawan memiliki pengaruh yang signifikan apabila dimediasi oleh kepuasan kerja. Pemimpin di industri perhotelan dapat meningkatkan kepuasan kerja karyawan dengan memberikan motivator yang berbeda bagi karyawan dalam bekerja dan oleh karena itu manajer juga harus lebih memperhatikan aspek pekerjaan yang berkaitan dengan kepuasan kerja.
\end{abstract}

Kata Kunci: Kepuasan Kerja, Kinerja, Hotel Budget, Budaya Organisasi, Kepemimpinan.

\begin{abstract}
The hospitality industry is facing a series of formidable challenges today. Some of these are relatively new, such as the rise in digital commerce, the increasing influence of mobile and social media, and the general decline in brand loyalty. In today's globalization challenges such as growing market opportunities, pressure on shareholders for short term results, continued lack of guest trust, and lack of talented employees. This research was conducted with a sample of 347 budget hotel employees from several budget hotel groups in the Jakarta area. The quantitative research method using SEM with the SmartPLS 3.0 tool used in this study aims to predict path analysis between constructs. Job satisfaction is also an important factor in hotel budgets because several factors that affect employee performance have a significant influence if mediated by job satisfaction. Leaders in the hospitality industry can increase employee job satisfaction by providing different motivators for employees at work and therefore managers should also pay more attention to job aspects related to job satisfaction.
\end{abstract}

Keywords: Job Satisfaction, Performance, Hotel Budget, Organizational Culture, Leadership.

How to Cite: Sembiring, V.B., Siregar, P.N.U.S. \& Fahlevi, M. (2021). Peran Kepuasan Kerja Sebagai Mediasi Variabel Terhadap Kinerja. JKBM (Jurnal Konsep Bisnis dan Manajemen). 8 (1): 104-113 


\section{INTRODUCTION}

The tourism industry can introduce Indonesia to the international world because Indonesia's natural wealth, cultural uniqueness, and natural beauty will attract foreign tourists to visit Indonesia. This increase in the tourism industry must be accompanied by good services and facilities owned by Indonesia. In research conducted by the Trip Advisor Index on several major hotels in the world, it is stated that Indonesia is a country that has the best and most profitable business prospects in the world in 2012 for the hotel business (Adiyanto \& Subakti, 2018). Good service and hotel provision is urgently needed by Indonesia because Indonesia's growing tourism industry requires a maximum level of service for the last two years to attract foreign tourists to Indonesia (Aksu, 2006).

Good service must be adjusted to the availability of the number of hotels, hotel rooms, and other accommodations as well as skilled workers in the tourism industry. Many developing countries cannot maximize the tourism industry in their country, so the availability of minimal facilities will reduce the desire of visitors to travel to the country (Fahlevi, 2021b; Gilbert \& Lockwood, 1990; Sahir et al., 2021). The increase in the number of non-hotel accommodations in the last two years was recorded at approximately 28,000 businesses and the total rooms reached 700,000. In this data, especially in the five-star hotel category, 3-star hotels are still dominated by 39\% of the number of star hotels in Indonesia (Badan Pusat Statistik, 2018). Now, people are more selective in finding vacation information, especially the price factor because it is easy to compare tickets and accommodation from various OTAs (Online Travel Agency) and other sites. This is what makes the trend of budget hotels quite attractive to tourists today. The budget hotel industry has also experienced an increase in recent times. Citing the e-Conomy SEA 2019 Report, the growth of budget hotels in Southeast Asia even increased 9 times in 2019 when compared to 2015, when the penetration of budget hotels in the tourism industry was just beginning.

In addition to the competitive price factor, the presence of budget hotels, which are currenttly able to provide convenience in the check-in to check-out process, and are able to provide good service and quality, are the driving factors for the rapid growth of this segment. Furthermore, from the consumer side, budget hotels that have competitive values in terms of price, quality, and location are also not only favored by backpacker tourists, but also families. Moreover, the staycation phenomenon is currently a growing trend in several big cities.

It has been predicted of course that the internet will become the main source for tourists to get information about holidays. Starting from plane tickets, accommodation, to tourism destination tickets, or culinary. Many OTAs (Online Travel Agencies) have provided this service, including room booking services for budget hotel options. National holidays and collective leave which in fact do not occur too long encourage people to take short vacations. Short vacations, such as the trend of staycations and short getaways, make budget hotels always a target for travelers who take advantage of this. Various kinds of information obtained on the internet 
trigger people to be selective in spending vacation expenses. Not to mention, given the many vacation opportunities, tourists tend to consider the budget, especially in terms of accommodation.

Airy's internal research also found that the Indonesian market is willing to spend an average of IDR 100,000 to IDR 300,000 per night for accommodation. Airy, as a pioneer in providing budget accommodation, is ready to answer the needs of this segment by presenting more than 2,000 properties and 30,000 rooms spread across more than 100 cities in Indonesia. With affordable prices and without compromising the comfort of its users' stay, Airy firmly sets the standard of Comfort Guarantee. Each Airy room provides at least seven main facilities: air conditioner, television, clean bed, drinking water, snacks, basic toiletries, and hot water

Dissatisfaction with the work that has been done can cause a decline in employee absenteeism every month, delays, complaining at work, lack of appreciation for the company and so on (Sembiring, 2021). This illustrates that dissatisfaction with unmet needs can affect employee performance. Based on the observations made by (Sitorus, 2019) To several employees at the budget hotels in South Jakarta, it is possible that there are different ways of leading that are applied by the leaders, causing both good and bad impacts. The good effects are: there are several employees who last a long time in work who started working from the newly established hotel until now. And the bad effects are like: there are employees who don't last long in a job that is only two weeks on the job. If employees have high productivity and work motivation, then the wheels will run well for a company. Therefore, The efforts of a leader in directing his staff to increase employee performance are a challenge because the company's success in accomplishing goals and survival is dependent on the quality of its human resources' performance.

The decline in performance is an important issue in the research of the hotel industry in Indonesia (Karir et al., 2019), because tourism is the leading sector and has experienced the largest increase. In some Asian countries such as Indonesia, tourism is a key sector in increasing the income of the population (Fahlevi et al., 2020). Service improvement in hospitality research must be carried out especially for budget hotels that have limited services. The limitations of budget hotels in obtaining human resources and minimal employee knowledge make services at budget hotels below average.

Research conducted by (Ruetz \& Marvel, 2011) in Europe and Asia explained that employee satisfaction is an important variable in improving the performance of hotel employees, especially in budget hotels, but the results of this study are different from research conducted by (Pawirosumarto et al., 2017) in Indonesia who found that employee satisfaction had no significant effect on the performance of hotel employees and even employee satisfaction could not mediate its effect on employee performance, on the contrary, leadership style became the strongest variable in its influence on employee performance (Al-Sada et al., 2017; Breevaart et al., 2016; Noonan, 2016). 


\section{RESEARCH METHODES}

The data obtained in this study will be numbers that will be examined using statistics, and it will be done using quantitative research methodologies (Saunders et al., 2009). This quantitative method applies deductive logic of thinking, i.e., from general to specific, from a general two-step communication flow to the performance of budget hotel staff as the study's subject. Because there is a separation between the researcher and the object being researched, this study is independent, as is quantitative research. This is a basic study, often known as pure research or basic research, with the purpose of enhancing scientific ideas and better understanding or prediction of business or other events (Fahlevi, 2021a). The SmartPLS analysis tool was utilized as a statistical tool to determine the influence of components in this investigation, which is a quantitative study (Fahlevi, 2021b).

Complex modeling often uses structural equation modeling (SEM) with various conditions that must be met. In some modeling these conditions are sometimes difficult to fulfill. An alternative that can be chosen while still applying complex modeling is Partial Least Square.

Techniques in collecting data in this study were conducted on employees and managers of budget hotels. This study uses purposive sampling so that the research is non-probability sampling (Lind et al., 2018), meaning that in this study the criteria for the sample are determined to clarify the sample object in this study (Sekaran \& Bougie, 2016). These criteria are intended so that the results of this research are measurable and clear when entering the analysis stage to be used as data analysis (Hair et al., 2017). The sample criteria in this study are as follows:

1. Employees and managers are active in budget hotels

2. Have 1 years of working experience in the hotel industry

3. Have a minimum educational background of senior high school

Based on the above criteria, the population in this study was 100 employees. Due to limitations in collecting the entire population, related to the current pandemic conditions, this study used a sample according to the formula described by (Slovin et al., 1993).

\section{RESULT AND DICSUSSION}

Respondent data in this study used the google form and offline forms, so that it could measure accurately in the assessment of each variable in this study. Although the respondent's data collection technique is anonymous, the respondent's background is needed as a complete data. The identity of the respondent is needed to know the demographics and background of the respondent as information material for this research. The questions before the respondent's questions in this research questionnaire are as follows:

Table 1. Profile Respondent

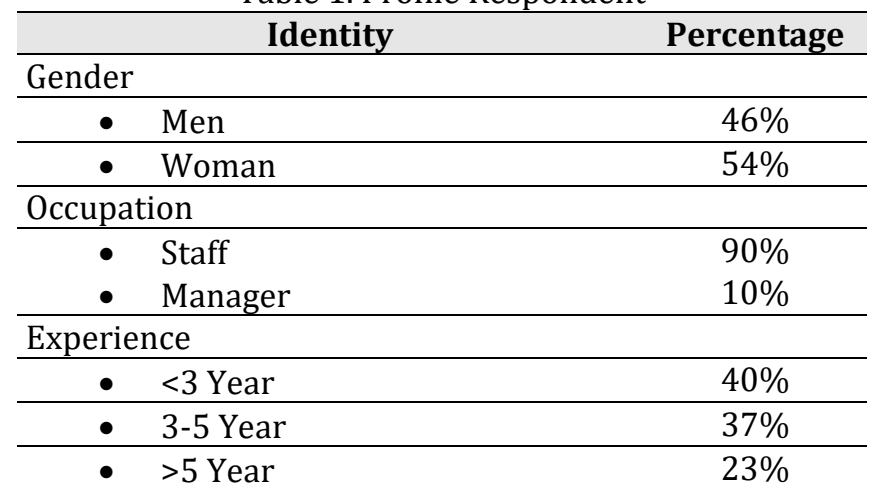


Sembiring, V.B., Siregar, P.N.U.S. \& Fahlevi, M. (2021). Peran Kepuasan Kerja Sebagai Mediasi Variabel Terhadap ...

\begin{tabular}{clc}
\hline \multicolumn{2}{c}{ Identity } & Percentage \\
\hline Education & \\
\hline$\bullet$ & High School & $63 \%$ \\
\hline$\bullet$ & Bachelor & $35 \%$ \\
\hline$\bullet$ & Master & $2 \%$ \\
\hline \multicolumn{2}{c}{ Data processed, 2021 }
\end{tabular}

At the next stage, the validity test is carried out, before analyzing the path model and hypothesis testing, first the validity of each indicator is tested using the Smart PLS 3 software. Individual reflexive measures are said to be valid if they have a loading value $(\lambda)$ with the latent variable to be measured 0,7 (rule of thumb), if one indicator item has a loading value $(\lambda)<0.7$ then the indicator must be eliminated (dropped) because it shows that the indicator is not good enough to measure the latent variable correctly (Hair et al., 2017) .

Another measure is the Average Variance Extracted (AVE) value. The AVE value describes the variance or diversity of the manifest variables that can be owned by the latent construct. In statistics (classical test theory), the mean extracted variance (AVE) is a measure of the amount of variance captured by the construct in relation to the amount of variance due to measurement error. The extracted mean variance is often used to assess discriminant validity based on the following "rule of thumb": Based on the corrected correlations of the CFA model, the AVE of each latent construct must be higher than the highest squared correlation with the other latent variables. If so, discriminant validity is established at the construct level. However, in simulation models this criterion is not proven to be reliable for variance-based structural equation models (eg PLS), but for covariance-based structural equation models (eg AMOS) only.
Thus, the greater the variance or diversity of the manifest variables that can be contained by the latent construct, the greater the representation of the manifest variable on the latent construct. Ghozali (2018) recommends the use of AVE for a criterion in assessing convergent validity. A minimum AVE value of 0.5 indicates a good measure of convergent validity. That is, the latent variable can explain the average of more than half the variance of the indicators. The AVE value is obtained from the sum of the squares of the loading factor divided by the error. The AVE measure can also be used to measure the reliability of the component score of latent variables and the results are more conservative than composite reliability (CR). If all indicators are standardized, then the AVE value will be equal to the average value of block communalities. Based on the table data above, it is known that the AVE value of all latent constructs is higher than 0.5 , so it can be classified as having good reliability.

Assessment of discriminant validity has become a generally accepted prerequisite for analyzing relationships between latent variables. For variance-based structural equation modeling, such as partial least squares. This validity test can be done by means of the Fornell-Larcker criteria and cross-loadings examination is the dominant approach to evaluate discriminant validity. The research in this thesis will only use cross-loading checks because carrying out the cross-loading test is sufficient to represent the discriminant test. The criterion for discriminant validity is that the 'loading' for each indicator is expected to be higher than the 'cross-loading' of each. If the Fornell-Larcker criterion assesses discriminant 
validity at the construct level (latent variable), then 'cross-loading' is possible at the indicator level.

Table 2. Discriminant Validity

\begin{tabular}{|c|c|c|c|}
\hline $\mathrm{X1}$ & $\mathrm{X} 2$ & $\mathbf{Y}$ & $\mathbf{Z}$ \\
\hline 0.638 & 0.577 & 0.536 & 0.499 \\
\hline 0.763 & 0.666 & 0.650 & 0.638 \\
\hline 0.835 & 0.740 & 0.702 & 0.690 \\
\hline 0.550 & 0.495 & 0.507 & 0.535 \\
\hline 0.826 & 0.758 & 0.696 & 0.693 \\
\hline 0.880 & 0.804 & 0.754 & 0.765 \\
\hline 0.868 & 0.809 & 0.760 & 0.740 \\
\hline 0.750 & 0.634 & 0.675 & 0.644 \\
\hline 0.810 & 0.728 & 0.749 & 0.687 \\
\hline 0.744 & 0.871 & 0.710 & 0.741 \\
\hline 0.742 & 0.906 & 0.735 & 0.749 \\
\hline 0.735 & 0.837 & 0.701 & 0.681 \\
\hline 0.726 & 0.858 & 0.736 & 0.750 \\
\hline 0.713 & 0.881 & 0.710 & 0.725 \\
\hline 0.709 & 0.895 & 0.786 & 0.785 \\
\hline 0.698 & 0.776 & 0.681 & 0.629 \\
\hline 0.651 & 0.776 & 0.711 & 0.710 \\
\hline 0.734 & 0.830 & 0.780 & 0.800 \\
\hline 0.748 & 0.800 & 0.781 & 0.749 \\
\hline 0.705 & 0.791 & 0.878 & 0.815 \\
\hline 0.595 & 0.679 & 0.654 & 0.605 \\
\hline 0.719 & 0.785 & 0.921 & 0.831 \\
\hline 0.744 & 0.724 & 0.843 & 0.769 \\
\hline 0.725 & 0.722 & 0.886 & 0.790 \\
\hline 0.687 & 0.667 & 0.828 & 0.755 \\
\hline 0.721 & 0.819 & 0.876 & 0.820 \\
\hline 0.666 & 0.637 & 0.809 & 0.693 \\
\hline 0.713 & 0.793 & 0.902 & 0.810 \\
\hline 0.665 & 0.731 & 0.729 & 0.833 \\
\hline 0.749 & 0.746 & 0.802 & 0.878 \\
\hline 0.712 & 0.755 & 0.805 & 0.891 \\
\hline 0.735 & 0.803 & 0.800 & 0.901 \\
\hline 0.720 & 0.784 & 0.777 & 0.875 \\
\hline 0.614 & 0.631 & 0.721 & 0.753 \\
\hline
\end{tabular}

Data processed, 2021

In the leadership style construct, items 1 and 4 have a lower value than loading on other constructs so that both items are deleted for maximum analysis results and prevent linkages between constructs in the realm of indicator items. In the organizational culture construct, indicator items 17 and 18 have a lower loading than loading on other constructs, so these two items must be removed. In the job satisfaction construct, item 22 has a lower loading than loading on other constructs, so this item must be removed. In the employee performance construct, item 35 has a lower loading than loading on other constructs, so this item must be deleted.

The value of the coefficient of impact between constructs is used to determine the influence directly or indirectly at this stage in order to test the hypothesis and evaluate the amount of the influence. According to Hair et al. (2011) By generating random cases with replacements from the original sample, the process generates a preset large number of bootstrap samples (e.g. 5,000 ) (Hair et al., 2019). The number of cases in each bootstrap sample must be the same as the number of instances in the original sample. Each bootstrap sample's SEM findings are estimated using the PLS technique. The standard deviation of the empirical sampling distribution is utilized as a proxy for the empirical standard error rate for that parameter, and iterative bootstrap parameter estimations are then used to generate an empirical sampling distribution for each model parameter. A bootstrap distribution is formed by the route model coefficients, which may be thought of as an approximation of the sampling distribution. The standard errors for each path model coefficient are calculated using PLS-SEM results from all bootstrap samples. The t-test in the study can be used with this information to determine the significance of the path model association.

Consider the sample as the best representation of budget hotel employees from the underlying population to understand this option. Although the data in this thesis does not reflect the complete population, it does provide a unique depiction of the popu- 
lation. Given that the model behind bootstrap is to use non-parametric maximum likelihood to estimate the cumulative distribution function, then take a sample of independent observations from the estimated cumulative distribution function, this truly random resampling of this population representation means that when used as a sample with replacement, resampling by resampling is done because it is the right thing to do..

The figure below will explain the path analysis for hypothesis testing as follows:

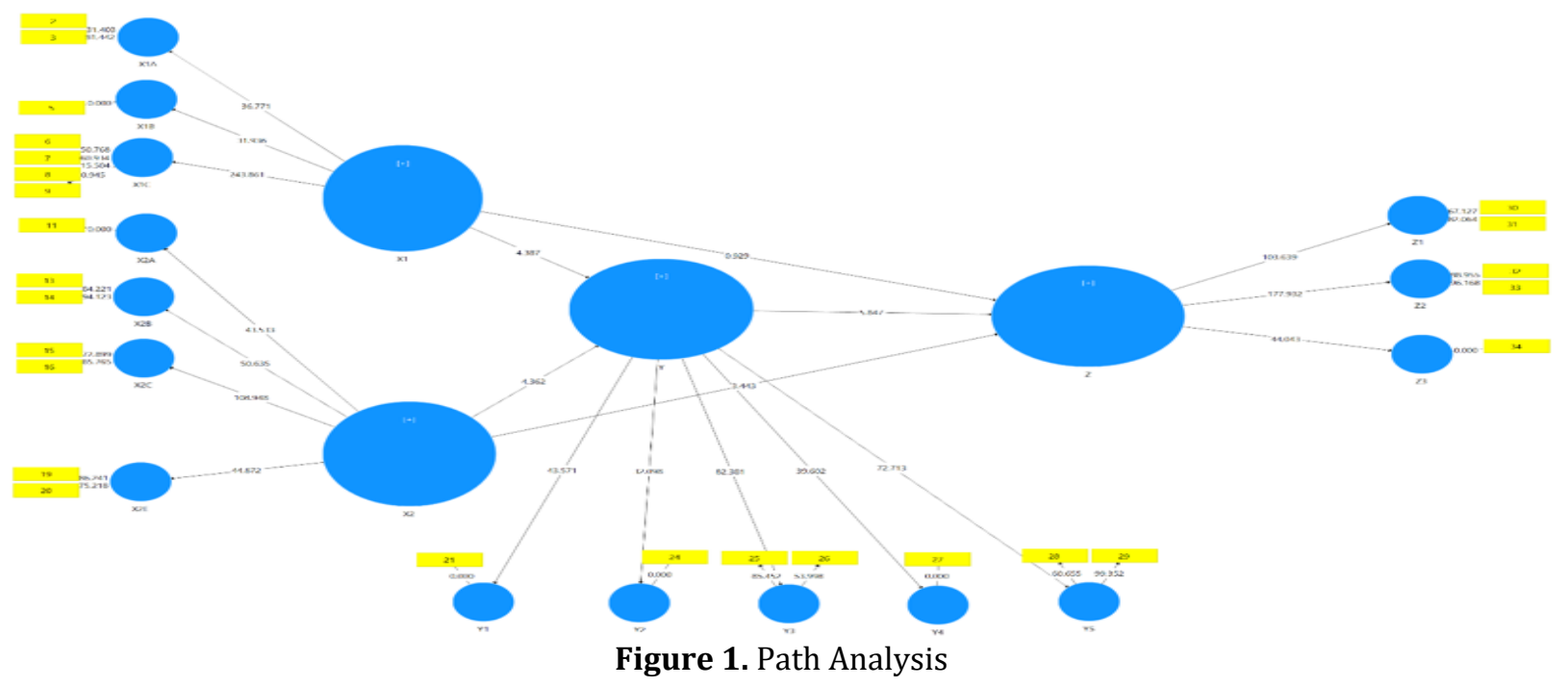

The results of the bootstrapping above are used to test the hypothesis, all of the indicator items in all constructs have a statistical value greater than 1.96. In conclusion, all of the indicator items above are able to measure the existing constructs. Meanwhile, to test the effect between variables, the statistical values from the Smart PLS analysis were compared with the table values. The following is a table that provides the results of the relationship between constructs.

The results above show that leadership style has a positive effect on employee performance with a coefficient value of 0.929 but it is not significant because it has a p-value $>0.05$. So it can be said that $\mathrm{H} 0$ is accepted and $\mathrm{H} 1$ is rejected. In the table above, it is known that organizational culture has a positive influence on employee performance with a coefficient value of 3.443 and has a significant effect because it has a p-value $<0.05$. So it can be said that $\mathrm{HO}$ is rejected and $\mathrm{H} 2$ is accepted. In the table above, it is known that job satisfaction has a positive effect on employee performance with a coefficient value of 5.847 and has a significant effect because it has a pvalue $<0.05$. So it can be said that $\mathrm{H} 0$ is rejected and H3 is accepted. In the table above, it is known that leadership style has a positive influence on job satisfaction with a coefficient value of 4.387 and has a significant effect because it has a p-value of $<0.05$. So it can be said that $\mathrm{HO}$ is rejected and $\mathrm{H} 4$ is accepted. In the table above, it is known that organizational culture has a positive influence on job satisfaction with a coefficient value of 4.362 and has a significant effect because it has a p-value $<0.05$. So it can be said that $\mathrm{H} 0$ is rejected and $\mathrm{H} 5$ is accepted. In the table above, it is known that leadership style through job satisfaction has a positive influence on employee performance indirectly with a coefficient value of 4.087 and has a significant effect because it has a p-value $<0.05$. So it can be said that $\mathrm{H} 0$ is rejected and $\mathrm{H} 6$ is accepted, in 
this case job satisfaction has succeeded in mediating because the direct influence of leadership style does not have a significant effect on employee performance. In the table above, it is known that organizational culture through job satisfaction has a positive influence on employee performance indirectly with a coefficient value of 2.944 and has a significant effect because it has a $p$-value of $<0.05$. So that it can be said that $\mathrm{HO}$ is rejected and $\mathrm{H} 7$ is accepted, in this result, although job satisfaction as a mediation has a significant value, the direct influence of organizational culture on employee performance is greater so that the mediation of job satisfaction has a lower effect even though it is significant.

Several literatures and previous research results explain that leadership style is an important factor to create motivated employees which in turn helps achieve organizational goals and therefore hospitality organizations must use effective leadership to improve guest services. In hospitality, a leader is characterized as a 'being there' style, which exerts pressure, intervention, and control over operations and interactions among members at all levels in the hotel service. This is part of the standard carried out by the management at Budget Hotel that the hotel manager, namely a director, has a schedule to participate in monitoring the work of subordinates, but those who have a regular schedule for being there are managers to assist hotel services.

Unlike the case with some inns at RedDoorz, the leadership style is more free and handed over to subordinates or 'hands-on' because the inn owners feel they have handed over their management to RedDoorz, the intensity of the staff as subordinates is actually more to the RedDoorz management than the inn owner as the leader. An employee at RedDoorz is delegated to make decisions such as refusing guests on some RedDoorz Syariah for suspicious guests and prohibition of providing extra mattresses or other decisions.

Based on the characteristics of the respondents in this study who are still relatively young and the majority of graduates from vocational schools still have very little work experience, the role of leadership is actually needed to guide them to work in the hotel industry (AlRasyid \& Puspita, 2018). In the sample of respondents there are many respondents who are contract employees, respondents are dominated by staff from Budget Hotel and most of them are contract employees. Based on observations and interviews with superiors, contract employees lack chemistry with other leaders or permanent employees. Contract employees are only used when the hotel requires additional workers during the holiday season. Managers or other workers who already have higher experience must arrange cooperation between them and contract employees as additionnal staff. Contract employees according to the manager's focus is the completion of the work but not the quality of the work. This is because during the holiday season when the Occupancy Rate increases, staff are also required to work fast.

For the phenomenon at RedDoorz due to limited staff, only RedDoorz Plus has permanent employees, in RedDoorz Basic all employees are contractual. This causes contract employees who have a fairly high turnover to study service standards at RedDoorz management briefly and 
usually have very minimal knowledge about guest services in the hospitality industry, because not all graduates from Hospitality Vocational Schools. In some cases in RedDoorz there are $\mathrm{Ow}^{-}$ ners staying at the inn but most of the RedDoorz, especially the Plus ones, have their own separate building from the Owner's residence, when the leader lives in the inn, the owner tends to oversee the service but not as strict as in Budget Hotel in terms of star hotel guest services, in other cases that are found in many RedDoorz Plus innkeepers who are not present at work only once a few weeks to check the condition of the inn, so that all operational decisions are left to their employees.

This study also explores the analysis of the dimensions, if referring to the results above, the highest coefficient value on leadership style based on its reflective construct is in the "Position Power" dimension, the meaning is the power possessed by a leader in controlling the hotel. The strength of this position has the primary purpose of ensuring that a group of people conform and work together towards a common goal set for the larger group.

The 'being there' or 'hands-on' managerial leadership style is considered a prevalent leadership style in the hospitality industry, this style can be more effective than other styles for obtaining employee job satisfaction, because managers work around the clock with their employees and therefore managers pay more attention to employee problems at work. In this study it is known that leadership style does not have a significant effect on employee performance, but when the influence of leadership style on employee performance through job satisfaction, the results are significant. Leadership style also has a strong and significant influence on job satisfaction, this can be seen in the large coefficient value between these two constructs.

\section{CONCLUSION}

In the budget hotel phenomenon, it is more appropriate if the hotel management uses the extra benefits given to employees who are nonfinancial due to the financial limitations of the budget hotel so that the hotel can use non-financial benefits such as lunch at work, rewards in the form of hotel vouchers or others. Budget hotels in Indonesia need to pay attention to important factors such as organizational culture and employee satisfaction in improving the performance of their employees. Employee performance is important in the hospitality industry that relies on service. Authoritarian leadership style has proven to be ineffective in budget hotels in Indonesia. Job satisfaction is an important factor so that budget hotels in Indonesia are expected to increase job satisfaction both financially and nonfinancially for their employees. Based on our results, a number of practical and managerial implycations can be derived. First, to increase the responsiveness of hotels to the needs of their customers, hotel managers need to have good leadership competencies by increasing their skills and knowledge in terms of self-management, strategic positioning, implementation, critical thinking, communication, and interpersonal relationships. Second, to improve the performance of hotel employees towards the needs of their customers, hotel managers also need to instill an organizational culture that is conducive to listening 
to their staff, giving rewards and recognition for their performance and caring for their welfare. Finally, given their ability to improve the performance of hotel employees through each of the variables in this study, managers can expect their hotel revenues to increase.

\section{REFERENCES}

Adiyanto, H., \& Subakti, A. G. (2018). Pengaruh Pelatihan, Motivasi dan Kompetensi Terhadap Kinerja Karyawan (Studi Kasus Hotel Sahid Jaya Lippo Cikarang). Journal of Indonesian Tourism, Hospitality and Recreation, 1(2), 55-69.

Aksu, A. A. (2006). Gap analysis in customer loyalty: A research in 5-star hotels in the Antalya region of Turkey. Quality and Quantity, 40(2), 187-205.

AlRasyid, H., \& Puspita, A. (2018). Gaya Kepemimpinan Pada Hotel Best Western Surabaya.

Al-Sada, M., Al-Esmael, B., \& Faisal, M. N. (2017). Influence of organizational culture and leadership style on employee satisfaction, commitment and motivation in the educational sector in Qatar. EuroMed Journal of Business.

Badan Pusat Statistik. (2018). Statistik Hotel Dan Akomodasi Lainnya Di Indonesia. BPS Statistics Indonesia, 186.

Breevaart, K., Bakker, A. B., Demerouti, E., \& Derks, D. (2016). Who takes the lead? A multi-source diary study on leadership, work engagement, and job performance. Journal of Organizational Behavior, 37(3), 309-325.

Fahlevi, M. (2021a). Mediating effect of motivation on employees' performance in a private hospital, Indonesia. 729(1), 012001.

Fahlevi, M. (2021b). Online consumer behaviour and its relationship to website atmospheric induced flow: Insights into online travel agencies in Indonesia. 729(1), 012114

Fahlevi, M., Rabiah, A. S., Pradipta, I. A., \& Marta, A. (2020). Tourism and Absorption of The Labor Force in Indonesia: A Strategy for Development. 16001, 26.

Ghozali, I. (2018). Aplikasi Analisis Multivariate dengan Program IBM SPSS 25. (Edisi 9). Semarang: Badan Penerbit Universitas Diponegoro.

Gilbert, D. C., \& Lockwood, A. (1990). Budget hotels-the USA, France and UK compared. Travel \& Tourism Analyst, 3, 19-35.

Hair, J. F., Hult, G. T. M., Ringle, C. M., \& Sarstedt, M. (2017). A Primer on Partial Least Squares Structural Equation Modeling (PLS-SEM) (2nd ed.). Sage.
Hair, J. F., Ringle, C. M., \& Sarstedt, M. (2011). PLS-SEM : Indeed a Silver Bullet PLS-SEM: Indeed a Silver Bullet. Journal of Marketing Theory and Practice, 19(2), 139-152. https://doi.org/10.2753/MTP1069-6679190202

Hair, J. F., Risher, J. J., Sarstedt, M., \& Ringle, C. M. (2019). When to use and how to report the results of PLSSEM. European Business Review.

Karir, P. P., Dan, K., Elsa, K., Dewi, O., \& Riana, I. G. (2019). PADA BINTANG KUTA HOTEL Fakultas Ekonomi dan Bisnis Universitas Udayana (Unud), Bali, Indonesia Berkembangnya suatu perusahaan tidak luput dari berbagai dukungan baik dukungan internal maupun eksternal perusahaan. Sumber Daya Manusia ( SDM) merupakan. 8(2), 7836-7862.

Lind, D. A., Marchal, W. G., \& Wathen, S. A. (2018). Statistical Techniques in Business \& Economics (17th ed., p. 897). McGraw Hill Education.

Noonan, J. (2016). Leadership in the Hotel Industry What it takes to be a CEO in today's global marketplace. SpencerStuart.

Pawirosumarto, S., Sarjana, P. K., \& Gunawan, R. (2017). The effect of work environment, leadership style, and organizational culture towards job satisfaction and its implication towards employee performance in Parador hotels and resorts, Indonesia. International Journal of Law and Management, 59(6), 1337-1358. https://doi.org/10.1108/IJLMA10-2016-0085

Ruetz, D., \& Marvel, M. (2011). Budget hotels: Low cost concepts in the US, Europe and Asia. In Trends and issues in global tourism 2011 (pp. 99-124). Springer.

Sahir, S. H., Sugito, S., Hasibuan, A., \& Fahlevi, M. (2021). Customer Experience Management: The Online Travel Agencies in Indonesia. ICIC Express Letters Part B: Applications, 12(4), 369-375.

Saunders, M., Lewis, P., \& Thornhill, A. (2009). Research Methods for Business Students (5th ed.). Prentice Hall.

Sekaran, U., \& Bougie, R. (2016). Research methods for business: A skill building approach. John Wiley \& Sons.

Sembiring, V. br. (2021). Human Capital Investment Development Strategy in Indonesia. Journal of Research in Business, Economics, and Education, 3(2), 1715-1721.

Sitorus, C. M. R. (2019). Pengaruh Kepemimpinan Terhadap Kinerja Karyawan di Hotel Fave Gatot Subroto Jakarta. Universitas Sahid.

Slovin, M. B., Sushka, M. E., \& Polonchek, J. A. (1993). The Value of Bank Durability: Borrowers as Bank Stakeholders. The Journal of Finance, 48(1), 247266. 